\title{
Deriving Freshwater Quality Criteria for Iron, Lead, Nickel, and Zinc for Protection of Aquatic Life in Malaysia
}

\author{
M. Shuhaimi-Othman, Y. Nadzifah, R. Nur-Amalina, and N. S. Umirah \\ School of Environmental and Natural Resource Sciences, Faculty of Science and Technology, Universiti Kebangsaan Malaysia (UKM), \\ Selangor, 43600 Bangi, Malaysia \\ Correspondence should be addressed to M. Shuhaimi-Othman, shuhaimi@ukm.my
}

Received 9 May 2012; Accepted 22 May 2012

Academic Editors: H. Grant and R. Pohjanvirta

Copyright ( $) 2012$ M. Shuhaimi-Othman et al. This is an open access article distributed under the Creative Commons Attribution License, which permits unrestricted use, distribution, and reproduction in any medium, provided the original work is properly cited.

\begin{abstract}
Freshwater quality criteria for iron $(\mathrm{Fe})$, lead $(\mathrm{Pb})$, nickel $(\mathrm{Ni})$, and zinc $(\mathrm{Zn})$ were developed with particular reference to aquatic biota in Malaysia, and based on USEPA's guidelines. Acute toxicity tests were performed on eight different freshwater domestic species in Malaysia which were Macrobrachium lanchesteri (prawn), two fish: Poecilia reticulata and Rasbora sumatrana, Melanoides tuberculata (snail), Stenocypris major (ostracod), Chironomus javanus (midge larvae), Nais elinguis (annelid), and Duttaphrynus melanostictus (tadpole) to determine $96 \mathrm{~h} \mathrm{LC}_{50}$ values for $\mathrm{Fe}, \mathrm{Pb}, \mathrm{Ni}$, and $\mathrm{Zn}$. The final acute value (FAV) for $\mathrm{Fe}, \mathrm{Pb}, \mathrm{Ni}$, and $\mathrm{Zn}$ were $74.5,17.0,165$, and $304.9 \mu \mathrm{g} \mathrm{L}^{-1}$, respectively. Using an estimated acute-to-chronic ratio (ACR) of 8.3, the value for final chronic value (FCV) was derived. Based on FAV and FCV, a criterion maximum concentration (CMC) and a criterion continuous concentration (CCC) for $\mathrm{Fe}, \mathrm{Pb}, \mathrm{Ni}$, and $\mathrm{Zn}$ that are 37.2, 8.5, 82.5, and 152.4 $\mu \mathrm{g} \mathrm{L}^{-1}$ and 9.0, 2.0, 19.9, and 36.7 $\mu \mathrm{g} \mathrm{L}^{-1}$, respectively, were derived. The results of this study provide useful data for deriving national or local water quality criteria for $\mathrm{Fe}, \mathrm{Pb}, \mathrm{Ni}$, and $\mathrm{Zn}$ based on aquatic biota in Malaysia. Based on $\mathrm{LC}_{50}$ values, this study indicated that N. elinguis, M. lanchesteri, N. elinguis, and $R$. sumatrana were the most sensitive to $\mathrm{Fe}, \mathrm{Pb}, \mathrm{Ni}$, and $\mathrm{Zn}$, respectively.
\end{abstract}

\section{Introduction}

Metal contamination has been shown to have serious effects on both the environment and humans. Malaysia, as a developing country, is no exception and faces metal pollution caused especially by anthropogenic activities such as manufacturing, agriculture, sewage, and motor vehicle emissions $[1,2]$. Studies on metals in water and sediments indicate that some rivers in Malaysia were contaminated with As, Ag, Cd, $\mathrm{Cu}, \mathrm{Pb}$, and $\mathrm{Zn}$ and some coastal sediments were contaminated by $\mathrm{Pb}, \mathrm{Zn}$, and $\mathrm{Cd}[1-4]$. However, Malaysia has a lack of water quality criteria (WQC) based on local aquatic biota. The existing water quality standards (WQSs) for metals in Malaysia (National Water Quality Standards) are based mainly on foreign criteria or standards, which have different environmental conditions compared to Malaysia. Many factors (physical, chemical, and biological) are known to affect the toxicity of metals to aquatic organisms. These factors, especially the differences in taxonomic composition of Malaysian waters compared to those for which WQSs were developed, could result in foreign water quality criteria or standards that are overprotective or underprotective for aquatic ecosystems in Malaysia. In order to protect aquatic ecosystems in Malaysia, it is necessary to develop WQC for metals based on the responses of domestic aquatic biota with local environmental factors. This information could also be used to determine sensitive and potential organisms as bioindicator for metal pollution especially in Malaysia.

Metals such as $\mathrm{Fe}, \mathrm{Pb}, \mathrm{Ni}$, and $\mathrm{Zn}$ are released from natural sources as well as human activity. Despite the adverse effects of metals on the environment and organisms, some metals are essential to living organisms. Zn plays an important role as a prosthetic group for the enzyme carbonic anhydrase while Fe in the respiratory protein haemoglobin [5]. Toxicity testing is an essential tool for assessing the effect and fate of toxicants in aquatic ecosystems and has been widely used as a tool to identify suitable organisms as a bioindicator and to derive water quality standards for 
chemicals [6]. Macroinvertebrate as a test organisms in toxicity tests have several valuable characteristics such as their widespread distribution and common occurrence in freshwater, their ecological importance and ease of handling during testing, as well as their rapid growth, short life cycle and sensitivity to contaminants $[7,8]$. Therefore, these organisms have the potential to act as a bioindicator of heavy metals pollution in an aquatic environment and as organisms for toxicity testing. USEPA [9] produced technical guidelines to give an objective way of deriving numerical national WQC. Acute to chronic ratios (ACRs) have been used extensively in ecological risk assessment to estimate the chronic toxicity of chemicals in aquatic organisms for which acute toxicity is known but data regarding chronic toxicity are either limited or absent. The "final acute value" (FAV) is often divided by an acute-to-chronic toxicity ratio (ACR) to estimate a chronic criterion that would not result in unacceptable adverse effects to aquatic communities. Although the ACR approach has weaknesses for criteria development or risk assessment, a major strength of the ACR approach is that it allows estimates of chronic values for acutely sensitive species to be made for which no chronic data are available. In such cases, direct analysis of available chronic data may underestimate chronic toxicity, whereas the ACR allows some extrapolation of chronic effects for sensitive species, even though no chronic data exists [10].

In this study, freshwater WQCs were developed for metals $(\mathrm{Fe}, \mathrm{Pb}, \mathrm{Ni}$, and $\mathrm{Zn}$ ) based on its acute toxicity to freshwater fish and invertebrates using domestic aquatic organisms. The toxicity data for $\mathrm{Fe}, \mathrm{Pb}, \mathrm{Ni}$, and $\mathrm{Zn}$ were generated by conducting acute toxicity testing with eight fish and invertebrate species and the Criterion Maximum Concentration (CMC) was derived. An estimated value of chronic data using acuteto-chronic ratio (ACR) was used to derive the Criterion Continuous Concentration (CCC). The overall objective of this study was to provide useful data to derive national or local water quality criteria for $\mathrm{Fe}, \mathrm{Pb}, \mathrm{Ni}$, and $\mathrm{Zn}$ based on aquatic biota indigenous in Malaysia.

\section{Materials and Methods}

2.1. Organisms and Test Chemicals. In this study eight local freshwater organisms have been used in toxicity testing, that is, a prawn Macrobrachium lanchesteri, two fish: Poecilia reticulata (guppy, family Poecilidae) and Rasbora sumatrana (family Cyprinidae), a snail (Gastropoda) Melanoides tuberculata (family Thiaridae), an ostracod Stenocypris major, a midge larvae Chironomus javanus (Diptera, Chironomidae), an annelid Nais elinguis, and a tadpole Duttaphrynus melanostictus. M. lanchesteri and R. sumatrana were obtained from local pet stores. P. reticulata, D. melanostictus, and M. tuberculata were collected from the field. N. elinguis, S. major, and C. javanus were collected from a fish pond filter system. Prior to toxicity testing, the organisms were acclimatized for one week under laboratory conditions $\left(28-30^{\circ} \mathrm{C}\right.$ with $12 \mathrm{~h}$ light: $12 \mathrm{~h}$ darkness) in 20 -L stocking tanks using dechlorinated tap water (filtered by several layer of sand and activated carbon; T.C. Sediment Filter
(TK Multitrade, Seri Kembangan, Malaysia)) and aerated through an air stone. During acclimation the organisms were fed with commercial fish food Tetramin (Tetrawerke, Germany). Four metals were used in this toxicity testing which were iron $(\mathrm{Fe})$, lead $(\mathrm{Pb})$, nickel $(\mathrm{Ni})$, and zinc $(\mathrm{Zn})$. The standard stock solution $\left(100 \mathrm{mg} \mathrm{L}^{-1}\right)$ of $\mathrm{Fe}, \mathrm{Pb}, \mathrm{Ni}$, and $\mathrm{Zn}$ were prepared from analytical grade metallic salts of $\mathrm{FeCl}_{3}, \mathrm{~Pb}\left(\mathrm{NO}_{3}\right)_{2}, \mathrm{NiSO}_{4} \cdot 6 \mathrm{H}_{2} \mathrm{O}$, and $\mathrm{ZnSO}_{4} \cdot 7 \mathrm{H}_{2} \mathrm{O}$ (Merck, Darmstadt, Germany). The stock solutions were prepared with deionized water in $1-\mathrm{L}$ volumetric.

2.2. Acute Toxicity Test. Acute $\mathrm{Fe}, \mathrm{Pb}, \mathrm{Ni}$, and $\mathrm{Zn}$ toxicity experiments were performed for a four-day period ( $96 \mathrm{~h}$ ) using adult animals or larvae (fourth instar midge larvae and tadpole). Following a range finding test, five $\mathrm{Fe}, \mathrm{Pb}, \mathrm{Ni}$, and $\mathrm{Zn}$ concentrations were chosen. Metal solutions were prepared by dilution of a stock solution with dechlorinated tap water. A control with dechlorinated tap water only was also used. The tests were carried out under static conditions with renewal of the solution every two days. Control and metal-treated groups each consisted of two to four replicates of five randomly allocated organisms. No significant stress was observed for the organisms in the solution indicated by $95-100 \%$ survival for the organism in the control water until the end of the study. For each species, a total of 10 to 20 animals per treatment (concentrations) were used in the experiment. Samples of water for metal analysis taken before and immediately after each solution renewal were acidified to $1 \%$ with ARISTAR nitric acid (65\%) (BDH Inc., VWR International Ltd., England) before metal analysis by flame or furnace Atomic Absorption Spectrophotometer (AASPerkin Elmer (MA, USA), model Analyst 800) depending on the concentrations. To avoid possible contamination, all glassware and equipment used were acid-washed $(20 \%$ $\mathrm{HNO}_{3}$ (Dongbu Hitek Co. Ltd., Seoul, Korea, 68\%)) and the accuracy of the analyses was checked against blanks. Procedural blanks and quality control samples made from standard solution for $\mathrm{Cu}, \mathrm{Cd}, \mathrm{Al}$, and $\mathrm{Mn}$ (Spectrosol, $\mathrm{BDH}$, England) were analysed in every ten samples in order to check for samples accuracy. Percentage recoveries for metals analyses were between $85-105 \%$. Details of the experiments can be found in Shuhaimi-Othman et al. [11-16].

During the toxicity test, organisms were not fed. The experiments were performed at room temperature of 28 $30^{\circ} \mathrm{C}$ with photoperiod $12 \mathrm{~h}$ light: $12 \mathrm{~h}$ darkness, using fluorescent lights (334-376 lux). Water quality parameters ( $\mathrm{pH}$, conductivity, and dissolved oxygen) were measured every two days using portable meters (model Hydrolab Quanta, Hach, Loveland, USA) and water hardness samples were fixed with ARISTAR nitric acid and measured by flame atomic absorption spectrophotometer (AAS-Perkin Elmer Analyst 800). Mortality was recorded every 3 to 4 hours for the first two days and then at 12 to 24 hour intervals throughout the test period. Any dead animals were removed immediately.

2.3. Statistical Analyses and Data Intergration. Median lethal concentrations $\left(\mathrm{LC}_{50}\right)$ for the animals exposed to $\mathrm{Fe}, \mathrm{Pb}$, 
$\mathrm{Ni}$, and $\mathrm{Zn}$ were calculated using measured metal concentrations. FORTRAN programs based on the methods of Litchfield [17] and Litchfield and Wilcoxon [18] were used to compute the $\mathrm{LC}_{50}$. Interpretation of toxicity data was conducted according to the methods described in the guidelines of USEPA [9]. Final acute value (FAV) was derived using the FAV equation in the guidelines. The criteria maximum concentration (CMC) was the FAV divided by two. To obtain the final chronic value (FCV), the FAV was divided by the ACR. ACRs have been used to estimate chronic toxicity for chemicals and species with known acute toxicity but limited or no information regarding chronic toxicity. In this study because no chronic data are available for species used in the acute toxicity study, an overall median value of 8.3 for the ACR was used, based on a study by Raimondo et al. [19] who derived a median value for ACR based on 456 same-species (invertebrate and fish) pairs of acute and maximum acceptable toxicant concentrations for metals, narcotics, pesticides, and other organic chemicals. The value of FCV was considered as the criterion continuous concentration (CCC).

\section{Results and Discussion}

The mean water quality parameters measured during the test were pH $6.68 \pm 0.2$, conductivity $180.3 \pm 4.6 \mu \mathrm{Scm}^{-1}$, dissolved oxygen $6.25 \pm 0.3 \mathrm{mg} \mathrm{L}^{-1}$, and total hardness $\left(\mathrm{Mg}^{2+}\right.$ and $\left.\mathrm{Ca}^{2+}\right) 18.72 \pm 1.72 \mathrm{mg} \mathrm{L}^{-1}$ as $\mathrm{CaCO}_{3}$. Results of acute toxicity tests using eight aquatic species (Table 1) showed that N. elinguis, M. lanchesteri, N. elinguis, and R. sumatrana were the most sensitive species to $\mathrm{Fe}, \mathrm{Pb}, \mathrm{Ni}$, and $\mathrm{Zn}$, respectively, while M. tuberculata, S. major, and C. javanus were the most resistant. Snail M. tuberculata was the most resistant to $\mathrm{Fe}$ and $\mathrm{Pb}$. According to Von Der Ohe and Liess [20] 13 taxa belonging to Crustacea were among the most sensitive to metal compounds, and they concluded that taxa belonging to Crustacea are similar to one another and to Daphnia magna in terms of sensitivity to organics and metals and that Molluscs have an average sensitivity to metals. Mitchell et al. [21] reported that the snail has a tightly sealing operculum that allows it to withstand desiccation and apparently also increases its tolerances to chemicals. Brix et al. [22] also reported that warm water fish, crustaceans other than cladocerans and other invertebrates were consistently of intermediate sensitivity and insects were the least sensitive taxonomic group evaluated for five metals $(\mathrm{Cd}, \mathrm{Cu}, \mathrm{Pb}, \mathrm{Ni}, \mathrm{Zn})$. N. elinguis is a freshwater worm from Naididae family and a cosmopolitan species that is abundant in organically enriched sites. N. elinguis was also reported to be the dominated worm in the activated sludge tank and sewage filter beds $[23,24]$. Chapman et al. [25] suggested that metal tolerances in aquatic oligochaetes are species-specific and worm tolerance to $\mathrm{Cd}$ and $\mathrm{Hg}$ were reverse of sewage sludge tolerances. Fish R. sumatrana was also found to be sensitive to Zn. Zakaria-Ismail and Fatimah [26] reported on the tolerance levels of common freshwater fish in Peninsular Malaysia and concluded that $R$. sumatrana has a medium tolerance level to pollutants with a value of 2.5 (value ranged from 0.5 being the most sensitive to 4.5 being the most tolerant species).

Comparison of toxicity between organisms in rank 1 (most sensitive) and 8 (most resistant) showed that for $\mathrm{Fe}$, $\mathrm{Pb}, \mathrm{Ni}$, and $\mathrm{Zn}$, the toxicity was $71,195,31$, and 12 times lower, respectively (Table 1). Differences in sensitivity for $\mathrm{Pb}$ were highest among the four metals studied. The difference seen for trace metals might be explained by metallothionein (MT) synthesis, which is believed to play a protective role against toxic metals in aquatic animals $[27,28]$. Other studies also provided evidence that the hypothalamic-pituitaryadrenocortical (HPA) axis, crucial in vertebrates coping with stressors, is one of the metal targets in several animal species, including teleost fish $[29,30]$. According to Luoma and Rainbow [5], the rank order of toxicity of metals will vary among organisms, and the factors that affect the rate of uptake of metals affect the toxicity of metal. Metal toxicity results when metals accumulate at an undesirable site(s) in the organisms and disrupt important molecular functions. Toxicity ensues once the threshold of metal availability has been passed, indicating that the rate of uptake exceeds both the rate of excretion and detoxification. Metals also can inhibit the uptake of major ions $\left(\mathrm{Na}^{+}, \mathrm{Ca}^{2+}, \mathrm{Mg}^{2+}, \mathrm{Cl}^{-}\right)$by freshwater organisms through either competitive or direct inhibition [31].

Using the FAV equation of USEPA [9], a final acute value (FAV) for $\mathrm{Fe}, \mathrm{Pb}, \mathrm{Ni}$, and $\mathrm{Zn}$ of $74.5,17,165$, and $304.9 \mu \mathrm{g} \mathrm{L}^{-1}$, respectively, was estimated. A criterion maximum concentration (CMC) for $\mathrm{Fe}, \mathrm{Pb}, \mathrm{Ni}$, and $\mathrm{Zn}$ of $37.2,8.5,82.5$, and $152.4 \mu \mathrm{g} \mathrm{L}^{-1}$, respectively, was obtained by dividing FAV values by 2 (Table 2 ). A criterion continuous concentration (CCC) was derived by dividing FAV values by ACR. In this study an ACR value of 8.3 was used based on the study by Raimondo et al. [19]. Based on the FAV and ACR values, a criterion continuous concentration (CCC) for $\mathrm{Fe}$, $\mathrm{Pb}, \mathrm{Ni}$, and $\mathrm{Zn}$ of 9.0, 2.0, 19.9, and $36.7 \mu \mathrm{g} \mathrm{L}^{-1}$, respectively, was obtained (Table 2). Comparison with other WQC or standards for metal from other countries is shown in Table 3. Results of this study were comparable with metal criteria from other countries such as the United States [32], Europe [33], and Canada [34]. However, USEPA standards for Pb which have been adjusted for water hardness $20 \mathrm{mg} \mathrm{L}^{-1}$ are lower than the present study. In comparison with current Malaysia water quality standards (National Water Quality Standard) NWQS, [2], values for the standard only given for Class II (clean) and no values for Class I (very clean) were given (only natural level are stated). Therefore the CCC and $\mathrm{CMC}$ values derived from this study are suggested to be used in the NWQS Malaysia.

In the present study, water hardness used was considered low $\left(18.7 \mathrm{mg} \mathrm{L}^{-1} \mathrm{CaCO}_{3}\right)$, and the water was categorized as soft water $\left(<75 \mathrm{mg} \mathrm{L}^{-1}\right.$ as $\left.\mathrm{CaCO}_{3}\right)$. Low water hardness has been known to increase metal toxicity to organisms [35-38]. This variance in toxicity is primarily the result of cations $\left(\mathrm{Ca}^{2+}, \mathrm{Mg}^{+}\right)$competing with metal ions for active binding sites with metal ions thereby limiting metal bioavailability. Most of the Malaysian freshwater ecosystem has low water hardness and normally less than $30 \mathrm{mg} / \mathrm{L} \mathrm{CaCO}_{3}$ such as freshwater lakes, Lake Chini with hardness $<10 \mathrm{mg} \mathrm{L}^{-1}$ [39], 
TABle 1: Acute toxicity of $\mathrm{Fe}, \mathrm{Pb}, \mathrm{Ni}$, and $\mathrm{Zn}$ to eight freshwater species (mean with $95 \%$ confidence limits).

\begin{tabular}{|c|c|c|c|}
\hline Metal & Rank & Species & $96 \mathrm{~h}-\mathrm{LC}_{50}\left(\mathrm{mg} \mathrm{L}^{-1}\right)$ \\
\hline \multirow{8}{*}{ Iron } & 1 & N. elinguis & $0.12(0.06-0.17)$ \\
\hline & 2 & S. major & $0.28($ n.a $)$ \\
\hline & 3 & D. melanostictus & 0.4 (n.a) \\
\hline & 4 & C. javanus & $0.62(0.004-1.25)$ \\
\hline & 5 & P. reticulata & $1.46(0.47-2.57)$ \\
\hline & 6 & R. sumatrana & $1.71(0.035-4.46)$ \\
\hline & 7 & M. lanchesteri & $3.42(0.35-32)$ \\
\hline & 8 & M. tuberculata & $8.49(1.58-15.25)$ \\
\hline \multirow{8}{*}{ Lead } & 1 & M. lanchesteri & $0.035(0.024-0.051)$ \\
\hline & 2 & S. major & $0.53(0.31-0.9)$ \\
\hline & 3 & N. elinguis & 0.58 (n.a) \\
\hline & 4 & R. sumatrana & $0.63(0.22-1.77)$ \\
\hline & 5 & C. javanus & $0.72(0.34-1.16)$ \\
\hline & 6 & D. melanostictus & $1.5(0.4-2.2)$ \\
\hline & 7 & P. reticulata & $1.99(0.69-4.14)$ \\
\hline & 8 & M. tuberculata & $6.82(2.89-12.67)$ \\
\hline \multirow{8}{*}{ Nickel } & 1 & N. elinguis & $0.64(0.56-0.69)$ \\
\hline & 2 & R. sumatrana & $0.83(0.30-1.56)$ \\
\hline & 3 & C. javanus & $5.32(2.79-9.21)$ \\
\hline & 4 & M. lanchesteri & $8.1(2.1-37.3)$ \\
\hline & 5 & M. tuberculata & $8.46(3.53-14.02)$ \\
\hline & 6 & D. melanostictus & $8.8(5-17)$ \\
\hline & 7 & P. reticulata & $15.62(10.77-20.56)$ \\
\hline & 8 & S. major & $19.74(14.77-26.38)$ \\
\hline \multirow{8}{*}{ Zinc } & 1 & R. sumatrana & $0.46(0.23-0.89)$ \\
\hline & 2 & M. lanchesteri & $0.52(0.33-0.88)$ \\
\hline & 3 & N. elinguis & $0.91(0.79-1.13)$ \\
\hline & 4 & P. reticulata & $1.05(0.37-2.15)$ \\
\hline & 5 & S. major & $1.19(0.95-1.48)$ \\
\hline & 6 & M. tuberculata & $3.9(1.81-6.67)$ \\
\hline & 7 & D. melanostictus & $4.2(2.1-7.5)$ \\
\hline & 8 & C. javanus & $5.57(3.54-29.42)$ \\
\hline
\end{tabular}

n.a-not available: values could not be calculated from probit software.

TABLE 2: FAV and CMC value for $\mathrm{Fe}, \mathrm{Pb}, \mathrm{Ni}$, and $\mathrm{Zn}$.

\begin{tabular}{lcccc}
\hline & $\mathrm{Fe}\left(\mu \mathrm{g} \mathrm{L}^{-1}\right)$ & $\mathrm{Pb}\left(\mu \mathrm{g} \mathrm{L}^{-1}\right)$ & $\mathrm{Ni}\left(\mu \mathrm{g} \mathrm{L}^{-1}\right)$ & $\mathrm{Zn}\left(\mu \mathrm{g} \mathrm{L}^{-1}\right)$ \\
\hline FAV & 74.5 & 17.0 & 165.0 & 304.9 \\
$\mathrm{CMC}=1 / 2$ FAV & 37.2 & 8.5 & 82.5 & 152.4 \\
$\mathrm{CCC}=$ FAV/ACR & 9.0 & 2.0 & 19.9 & 36.7 \\
\hline
\end{tabular}

${ }^{*} \mathrm{ACR}=8.3$ (from Raimondo et al. [19]).

Lake Bera with hardness $5.4 \mathrm{mg} \mathrm{L}^{-1}[40]$, and Lake Bukit Merah with hardness $5 \mathrm{mg} \mathrm{L}^{-1}$ [41], and rivers such as Bebar River with hardness $<10 \mathrm{mg} \mathrm{L}^{-1}$ [42], Kelantan River with hardness $16.1 \mathrm{mg} \mathrm{L}^{-1}$ [43] and Langat River with hardness $23.4 \mathrm{mg} \mathrm{L}^{-1}$ [44], and this has made the organisms sensitive to metal pollution. In addition, a comparison of metal concentrations in some rivers of Malaysia, such as Langat, Gombak, Mamut, and Linggi rivers, showed the $\mathrm{Pb}$ and $\mathrm{Zn}$ concentrations to be between $22-75 \mu \mathrm{g} \mathrm{L}^{-1}, 10-42 \mu \mathrm{g} \mathrm{L}^{-1}, 2-$ $22 \mu \mathrm{g} \mathrm{L}^{-1}$ and $0.28-0.84 \mathrm{mg} \mathrm{L}^{-1}$, respectively [45-48], which were higher than the CMC or CCC values derived from this study. Therefore, the high metal concentration in the water and the low water hardness has made the Malaysian freshwater ecosystem vulnerable and sensitive to metal contamination.

A comparison on toxicity of metals to freshwater organisms revealed that among the four metals studied, $\mathrm{Pb}$ was the most toxic to the organisms followed by $\mathrm{Fe}, \mathrm{Ni}$, and $\mathrm{Zn}$. Based on other international standards (Table 3), all the standards (USEPA, CCME, and UNECE) categories of $\mathrm{Pb}$ 
TABLE 3: Comparison criteria of metal concentration in freshwater ecosystem.

\begin{tabular}{lcccc}
\hline & $\mathrm{Fe}\left(\mu \mathrm{g} \mathrm{L}^{-1}\right)$ & $\mathrm{Pb}\left(\mu \mathrm{g} \mathrm{L}^{-1}\right)$ & $\mathrm{Ni}\left(\mu \mathrm{g} \mathrm{L}^{-1}\right)$ & $\mathrm{Zn}\left(\mu \mathrm{g} \mathrm{L}^{-1}\right)$ \\
\hline This study & $\mathrm{CMC}=37.2$ & $\mathrm{CMC}=8.5$ & $\mathrm{CMC}=82.5$ & $\mathrm{CMC}=152.4$ \\
& $\mathrm{CCC}=9.0$ & $\mathrm{CCC}=2.0$ & $\mathrm{CCC}=19.9$ & $\mathrm{CCC}=36.7$ \\
USEPA & n.a. & $\mathrm{CMC}=10.8^{*}$ & $\mathrm{CMC}=120^{*}$ & $\mathrm{CMC}=30^{*}$ \\
& & $\mathrm{CCC}=0.42^{*}$ & $\mathrm{CCC}=13.3^{*}$ & $\mathrm{CCC}=30^{*}$ \\
CCME & 300 & 1 & 25 & 30 \\
UNECE (Class I) & n.a. & $<0.1$ & $<15$ & $<45$ \\
NWQS (Class II) & 1000 & 50 & 50 & 5000 \\
\hline
\end{tabular}

Sources: CCME [34]; NWQS [2]; USEPA [32]; UNECE [33].

n.a.-not available.

*For water hardness $20 \mathrm{mg} \mathrm{L}^{-1}$.

were the most toxic to freshwater organisms among the four metals tested. Many studies also showed that $\mathrm{Pb}$ was more toxic than $\mathrm{Zn}, \mathrm{Ni}$, or $\mathrm{Fe}$ to freshwater organisms such as the worm Lumbriculus variegatus [49] and Tubifex tubifex [50], midge larvae Chironomus riparius [51] and Chironomus tendipes [52]. Khangarot [50] explained that most of the heavy metal ions are toxic to living organisms because they combine with some ligands of enzymes which are necessary for life. However, for nontransitional metal cation, enzyme inhibition is not likely to be a primary cause of toxicity. But osmotic or other colligative factors working through physical reactions cause physical damage to the cellular system.

The CMC and CCC values of $\mathrm{Fe}, \mathrm{Pb}, \mathrm{Ni}$, and $\mathrm{Zn}$ obtained in our study will provide useful data from which national and local WQC for metals can be derived. The guidelines were developed on the theory that effects which occur on a species in appropriate laboratory tests will generally occur on the same species in comparable field conditions. A numerical WQC can be considered as the highest concentration of a certain substance that would not cause any unacceptable long-term or short-term effect on the aquatic organisms or their use. Because aquatic ecosystems can tolerate some stress and occasional adverse effects, it is not necessary to protect all species at all times and places. Therefore, the purpose of deriving numerical national WQC is not to provide the same concentration at any time for the survival and the reproduction of all species in a specific ecosystem, but to provide adequate protection to ecologically and commercially important species in waters at most times, and to avoid overprotection or underproduction [9].

\section{Conclusions}

This study has shown that among the four metals tested on freshwater organisms, $\mathrm{Pb}$ was the most toxic, followed by $\mathrm{Fe}, \mathrm{Ni}$, and $\mathrm{Zn}$. The $\mathrm{CMC}$ and $\mathrm{CCC}$ values for $\mathrm{Fe}, \mathrm{Pb}, \mathrm{Ni}$, and $\mathrm{Zn}$ estimated from this study are 37.2, 8.5, 82.5, and $152.4 \mu \mathrm{g} \mathrm{L}^{-1}$, and 9.0, 2.0, 19.9, and $36.7 \mu \mathrm{g} \mathrm{L}^{-1}$, respectively. These values are suggested to be used in Malaysian WQC for metals in freshwater ecosystems for the protection of aquatic life.

\section{Acknowledgments}

This study was funded by the Ministry of Science, and Technology and Innovation (MOSTI), Malaysia, under eScience fund code no. 06-01-02-SF0217 and UKM-OUPFST-2012. The authors do not have any direct financial relation with the commercial identity mentioned in this paper.

\section{References}

[1] N. A. M. Shazili, K. Yunus, A. S. Ahmad, N. Abdullah, and M. K. A. Rashid, "Heavy metal pollution status in the Malaysian aquatic environment," Aquatic Ecosystem Health and Management, vol. 9, no. 2, pp. 137-145, 2006.

[2] Department of Environment, "Malaysia environment quality report 2008,” Tech. Rep. ISSN 0127-6433, Department of Environment, Ministry of Natural Resources and Environment, Malaysia, 2009.

[3] S. Z. Zulkifli, F. Mohamat-Yusuff, T. Arai, A. Ismail, and N. Miyazaki, "An assessment of selected trace elements in intertidal surface sediments collected from the Peninsular Malaysia," Environmental Monitoring and Assessment, vol. 169, no. 1-4, pp. 457-472, 2010.

[4] C. K. Yap and B. H. Pang, "Assessment of Cu, Pb, and $\mathrm{Zn}$ contamination in sediment of north western Peninsular Malaysia by using sediment quality values and different geochemical indices," Environmental Monitoring and Assessment, pp. 23-39, 2011.

[5] S. N. Luoma and P. S. Rainbow, Metal Contamination in Aquatic Environment: Science and Lateral Management, Cambridge, New York, NY, USA, 2008.

[6] W. J. Adams and C. D. Rowland, "Aquatic toxicology test methods," in Handbook of Ecotoxicology, D. J. Hoffman, B. A. Rattner, G. A. Burton Jr., and J. Cairns Jr., Eds., Lewis Publisher, CRC Press, Boca Raton, FLa, USA, 2nd edition, 2003.

[7] D. Pascoe and R. W. Edwards, "Single species toxicity tests," in Aquatic Ecotoxicology-Fundamental, Concepts and Methodologies, A. Boudou and F. Ribeyre, Eds., pp. 99-144, CRC Press, Boca Raton, Fla, USA, 1989.

[8] EPS (Environmental Protection Series), "Biological test method: test for survival and growth in sediment using the freshwater amphipod Hyalella azteca," Tech. Rep. EPS1/RM/33, 1997.

[9] USEPA (United State Environmental Protection Agency), "Guideline for deriving numerical national water quality 
criteria for the protection of aquatic organisms and their uses," Tech. Rep. number PB85227049, USEPA, Washington, DC, USA, 1985.

[10] D. R. Mount, G. T. Ankley, K. V. Brix, W. H. Clements, D. G. Dixon, and A. Fairbrother, "Effects assessment," in Reevaluation of the State of the Science for Water-Quality Criteria Development, M. C. Reiley, W. A. Stubblefield, W. J. Adams et al., Eds., pp. 53-118, SETAC Press, Pensacola, Fla, USA, 2003.

[11] M. Shuhaimi-Othman, Y. Nadzifah, N. Shahirul-Umirah, and A. Ahmad, "Toxicity of eight metals to Malaysian freshwater midge larvae Chironomus javanus (Diptera, Chironomidae)," Toxicology and Industrial Health, vol. 27, no. 10, pp. 879-886, 2011.

[12] M. Shuhaimi-Othman, N. Yakub, N. A. Ramle, and A. Abas, "Toxicity of metals to a freshwater ostracod: Stenocypris major," Journal of Toxicology, vol. 2011, Article ID 136104, 2011.

[13] M. Shuhaimi-Othman, N. Yakub, N. A. Ramle, and A. Abas, "Sensitivity of the freshwater prawn, Macrobrachium lanchesteri (Crustacea: Decapoda), to heavy metals," Toxicology and Industrial Health, vol. 27, no. 6, pp. 523-530, 2011.

[14] M. Shuhaimi-Othman, Y. Nadzifah, N. S. Umirah, and A. K. Ahmad, "Toxicity of metals to tadpoles of common Sunda toad, Duttaphrynus melanostictus," Toxicological and Environmental Chemistry, vol. 94, no. 2, pp. 364-376, 2012.

[15] M. Shuhaimi-Othman, N. Yakub, N. A. Ramle, and A. Abas, "Comparative metal toxicity to freshwater fish," Journal of Toxicology and Industrial Health. In press.

[16] M. Shuhaimi-Othman, R. Nur-Amalina, and Y. Nadzifah, "Toxicity of metals to a freshwater snail, Melanoides tuberculata," The Scientific World Journal, vol. 2012, Article ID 125785 , 10 pages, 2012.

[17] T. J. Lichfield, "A method for the rapid graphic solution of time-percentage effect curves," Journal of Pharmacology and Experimental Therapeutics, vol. 97, pp. 399-408, 1949.

[18] T. J. Lichfield and F. Wilcoxon, "A simplified method of evaluating dose effect experiments," Journal of Pharmacology and Experimental Therapeutics, vol. 96, pp. 99-113, 1949.

[19] S. Raimondo, B. J. Montague, and M. G. Barron, "Determinants of variability in acute to chronic toxicity ratios for aquatic invertebrates and fish," Environmental Toxicology and Chemistry, vol. 26, no. 9, pp. 2019-2023, 2007.

[20] P. C. Von Der Ohe and M. Liess, "Relative sensitivity distribution of aquatic invertebrates to organic and metal compounds," Environmental Toxicology and Chemistry, vol. 23, no. 1, pp. 150-156, 2004.

[21] A. J. Mitchell, M. S. Hobbs, and T. M. Brandt, "The effect of chemical treatments on red-rim melania Melanoides tuberculata, an exotic aquatic snail that serves as a vector of trematodes to fish and other species in the USA," North American Journal of Fisheries Management, vol. 27, no. 4, pp. 1287-1293, 2007.

[22] K. V. Brix, D. K. DeForest, M. Burger, and W. J. Adams, "Assessing the relative sensitivity of aquatic organisms to divalent metals and their representation in toxicity datasets compared to natural aquatic communities," Human and Ecological Risk Assessment, vol. 11, no. 6, pp. 1139-1156, 2005.

[23] M. A. Learner, "The distribution and ecology of the Naididae (Oligochaeta) which inhabit the filter-beds of sewage-works in Britain," Water Research, vol. 13, no. 12, pp. 1291-1299, 1979.

[24] C. H. Ratsak, "Effects of Nais elinguis on the performance of an activated sludge plant," Hydrobiologia, vol. 463, pp. $217-$ 222, 2001.
[25] P. M. Chapman, M. A. Farrell, and R. O. Brinkhurst, "Relative tolerances of selected aquatic oligochaetes to combinations of pollutants and environmental factors," Aquatic Toxicology, vol. 2, no. 1, pp. 69-78, 1982.

[26] M. Zakaria-Ismail and A. Fatimah, "Fish index for classifying riverine ecosystem of Peninsular Malaysia," Malaysian Journal of Science, vol. 21, pp. 1-7, 2002.

[27] G. Roesijadi, "Metallothioneins in metal regulation and toxicity in aquatic animals," Aquatic Toxicology, vol. 22, no. 2, pp. 81-114, 1992.

[28] L. Hollis, C. Hogstrand, and C. M. Wood, "Tissue-specific cadmium accumulation, metallothionein induction, and tissue zinc and copper levels during chronic sublethal cadmium exposure in juvenile rainbow trout," Archives of Environmental Contamination and Toxicology, vol. 41, no. 4, pp. 468-474, 2001.

[29] A. Hontela, "Endocrine and physiological responses of fish to xenobiotics: role of glucocorticosteroid hormones," Reviews in Toxicology, vol. 1, no. 5-6, pp. 1-46, 1997.

[30] D. O. Norris, S. Donahue, R. M. Dores et al., "Impaired adrenocortical response to stress by brown trout, Salmo trutta, living in metal-contaminated waters of the Eagle River, Colorado," General and Comparative Endocrinology, vol. 113, no. 1, pp. 1-8, 1999.

[31] K. V. Brix, D. K. DeForest, and W. J. Adams, "The sensitivity of aquatic insects to divalent metals: a comparative analysis of laboratory and field data," Science of the Total Environment, vol. 409, no. 20, pp. 4187-4197, 2011.

[32] USEPA (United State Environmental Protection Agency), "National Recommended Water Quality Criteria," Tech. Rep. Washington, DC, USA, Office of Science and Technology, 2005.

[33] UNECE, "Standard statistical classification of surface freshwater quality for the maintenance of aquatic life," in Reading in International Environment Statistics, United Nations Economic Commission for Europe, New York, NY, USA, 1994.

[34] CCME, Canadian Environmental Quality Guidelines, Canadian Council of Ministers of the Environment, Winnipeg, Canada, 1999.

[35] C. P. McCahon and D. Pascoe, "Use of Gammarus pulex (L.) in safety evaluation tests: culture and selection of a sensitive life stage," Ecotoxicology and Environmental Safety, vol. 15, no. 3, pp. 245-252, 1988.

[36] R. Singh Rathore and B. S. Khangarot, "Effects of water hardness and metal concentration on a freshwater Tubifex tubifex muller," Water, Air, and Soil Pollution, vol. 142, no. 1-4, pp. 341-356, 2003.

[37] J. Gorski and D. Nugegoda, "Sublethal toxicity of trace metals to larvae of the blacklip abalone, Haliotis rubra," Environmental Toxicology and Chemistry, vol. 25, no. 5, pp. 1360-1367, 2006.

[38] M. Ebrahimpour, H. Alipour, and S. Rakhshah, "Influence of water hardness on acute toxicity of copper and zinc on fish," Toxicology and Industrial Health, vol. 26, no. 6, pp. 361-365, 2010.

[39] M. Shuhaimi-Othman, I. Mushrifah, E. C. Lim, and A. Ahmad, "Trend in metals variation in Tasik Chini, Pahang, Peninsular Malaysia," Environmental Monitoring and Assessment, vol. 143, no. 1-3, pp. 345-354, 2008.

[40] I. Ikusima, R. P. Lim, and J. I. Furtado, "Environmental conditions," in Tasek Bera: The Ecology of a Freshwater Swamp, J. I. Furtado and S. Mori, Eds., pp. 55-148, Junk Publishers, The Hague, The Netherlands, 1982. 
[41] M. Shuhaimi-Othman, A. K. Ahmad, and G. Norziana, "Metal concentrations in Bukit Merah Lake, perak," Sains Malaysiana, vol. 39, no. 6, pp. 883-889, 2010.

[42] M. Shuhaimi-Othman, A. K. Ahmad, and E. C. Lim, "Metals concentration in water and sediment of Bebar peat swampy forest river, Malaysia," Journal of Biological Sciences, vol. 9, no. 7, pp. 730-737, 2009.

[43] A. K. Ahmad, I. Mushrifah, and M. Shuhaimi-Othman, "Water quality and heavy metal concentrations in sediment of Sungai Kelantan, Kelantan, Malaysia: a baseline study," Sains Malaysiana, vol. 38, no. 4, pp. 435-442, 2009.

[44] H. Juahir, S. M. Zain, M. K. Yusoff et al., "Spatial water quality assessment of Langat River Basin (Malaysia) using environmetric techniques," Environmental Monitoring and Assessment, vol. 173, no. 1-4, pp. 625-641, 2011.

[45] A. Hamzah, M. P. Abdullah, S. Sarmani, and M. A. Johari, "Chemical and bacteriological monitoring of drinking water from an urbanised water catchment drainage basin," Environmental Monitoring and Assessment, vol. 44, no. 1-3, pp. 327338, 1997.

[46] M. Shuhaimi-Othman and A. R. Nurlailawati, "Study of metals concentration $(\mathrm{Cu}, \mathrm{Cd}, \mathrm{Zn}$ and $\mathrm{Pb})$ in water, sediment and freshwater shrimp Macrobrachium sp. in Langat River, Selangor," Malaysian Journal of Analytical Sciences, vol. 8, pp. 117-122, 2004.

[47] M. F. Ali, L. Y. Heng, W. Ratnam, J. Nais, and R. Ripin, "Metal distribution and contamination of the Mamut River, Malaysia, caused by copper mine discharge," Bulletin of Environmental Contamination and Toxicology, vol. 73, no. 3, pp. 535-542, 2004.

[48] Z. Ismail, B. Primasari, and S. M. Shirazi, "Monitoring and management issues of heavy metal pollution of Gombak River, Kuala Lumpur," International Journal of the Physical Sciences, vol. 6, no. 35, pp. 7961-7968, 2011.

[49] H. C. Bailey and D. H. W. Liu, "Lumbriculus variegatus, a benthic Oligochaete, as a bioassay organism," in Aquatic Toxicology and Hazard Assessment, STP 707, pp. 205-215, ASTM, Philadelphia, Pa, USA, 1980.

[50] B. S. Khangarot, "Toxicity of metals to a freshwater tubificid worm, Tubifex tubifex (Muller)," Bulletin of Environmental Contamination and Toxicology, vol. 46, no. 6, pp. 906-912, 1991.

[51] K. M. Béchard, P. L. Gillis, and C. M. Wood, "Acute toxicity of waterborne $\mathrm{Cd}, \mathrm{Cu}, \mathrm{Pb}, \mathrm{Ni}$, and $\mathrm{Zn}$ to first-instar Chironomus riparius larvae," Archives of Environmental Contamination and Toxicology, vol. 54, no. 3, pp. 454-459, 2008.

[52] D. S. Rao and A. B. Saxena, "Acute toxicity of mercury, zinc, lead, cadmium, manganese to the Chironomus Sp.", International Journal of Environmental Studies, vol. 16, no. 3-4, pp. 225-226, 1981. 

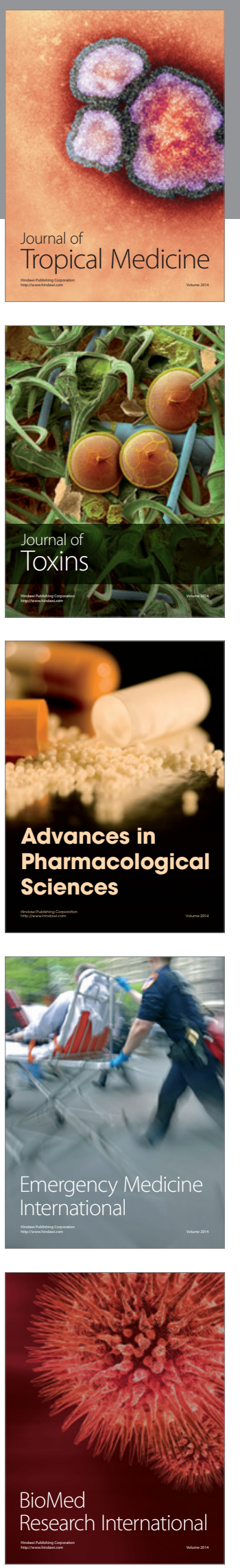
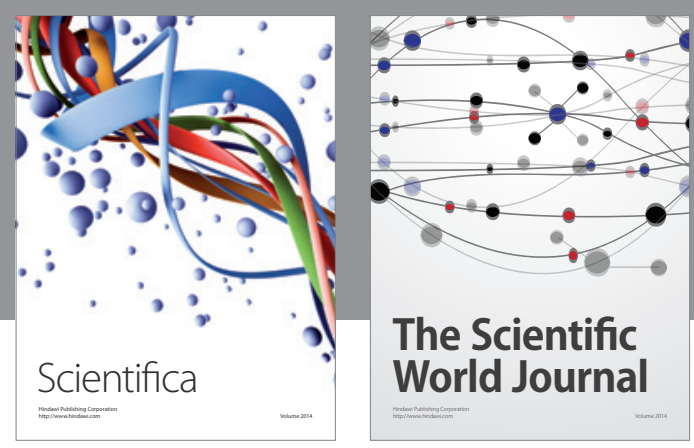

The Scientific World Journal
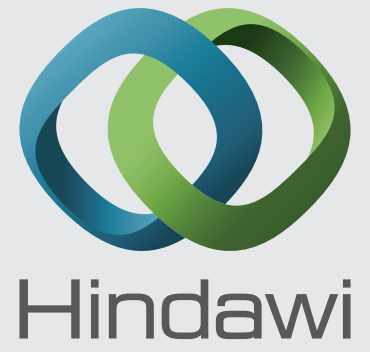

Submit your manuscripts at

http://www.hindawi.com
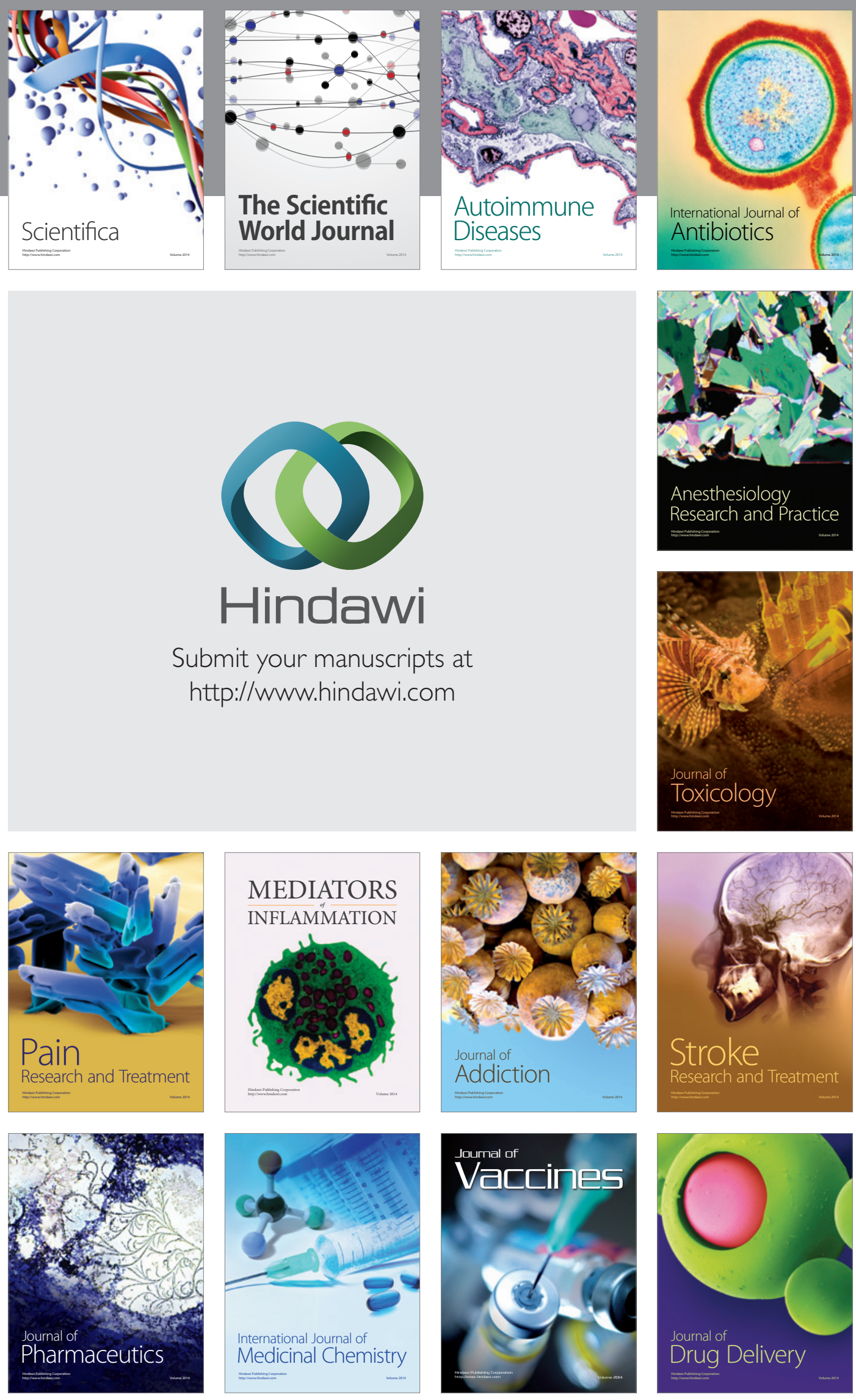